\title{
A STUDY ON THE PROFITABILITY ANALYSIS OF PRIVATE LIFE INSURERS: A COMPARATIVE STUDY OF ICICI PRUDENTIAL LIFE AND HDFC LIFE
}

\author{
MONA JINDAL
}

S. S. D Women's Institute of Technology, Bathinda, India

\begin{abstract}
Profitability is one of the most important objectives of financial management, because one of the major goals of financial management is to maximize the owner's wealth. Performance in business enterprises has attracted researcher's attention in the literature of corporate finance over the past decades. However, in the context of the insurance sector, not much attention has been given. There are many factors to consider while looking at insurance companies. The paper focuses on the performance of private life insurance companies for the period from 2002to 2014. In order to accomplish the aim, the study determines the impact of liquidity, solvency, leverage, size, age and equity capital on the profitability of life insurers in India. The sample for this study includes top two Indian life insurers and it analyses the data of 13 years from 2001-2002 to 2013-2014. The study uses multiple linear regression model to measure the extent to which these determinants exert impact on life insurers profitability.

KEYWORDS: Liquidity, Solvency, Leverage, Size, Age \& Equity Capital
\end{abstract}

Received: Apr 28, 2017; Accepted: May 20, 2017; Published: Jun 06, 2017; Paper Id.: IJAFMRJUN20171

\section{INTRODUCTION}

Insurance can be defined as a service that provides a benefit upon the occurrence of a risk. Delivery, usually financial, may be for an individual, association or business in exchange for a perceived contributions or premiums. Thus, insurance is the equitable transfer of the risk of a loss, from one entity to another, in exchange for a premium and can be thought of as a guaranteed known small loss to prevent a large, possibly devastating loss. Life insurance can be defined as a contract between the policy owner and the insurer, where the insurer agrees to pay a sum of money upon the occurrence of the insured individuals' death or some other event, such as terminal illness or critical illness.

\section{Comparative Analysis of Top 2 Private Life Insurance Companies (PLIC's)}

In the study, performance evaluation is done of Top 2 PLIC's namely ICICI Prudential Life and HDFC Life based on their general market share capacity. Various performance indicators are identified and studied. On the basis of which, suggestion will be given for the future improvements.

\section{REVIEW OF LITERATURE}

Suresh (2009): In his study 'Recipe for Successful life insurance business assessed the importance of distributor playing the role of first level professional in life insurance business. Treating the customer fairly is a new management initiative that looks beyond mere customer satisfaction. He emphasized that insurer should ensure that though customer is fully satisfied with services, but if not treated fairly on account of ignorance of what was 
actually due to him it would demand change in practice.

Udaychandran (2010): In his paper 'Need for Variety in Product' says that there is need for new products, particularly long term in nature, especially in health insurance sector. Health savings account would be a wise proposition and by designing the product, that would be outstandingly unique, but given that it should be within the constraints of regulatory approval. It also studied the performance of the products that have already been introduced in the market and wherever necessary, appropriate changes must be made, it must be in tune with that of customer demands. For this, imaginative combination of riders with base products could lead to better solutions.

Parekh (2011): In his paper 'Corporate social responsibility in Insurance' emphasis to put on improvement of awareness among masses by educating them about preventive healthcare, adoption of general hygiene, arresting the rate of accidents, etc. Though it sounds very mundane, there is a need of hour for spreading awareness in these aspects, especially in rural and under developed areas. He found that these attempts could lead to better business results for the insurers showing positive results in visible development of the society.

\section{OBJECTIVES OF THE STUDY}

The present study made an attempt to examine the financial performance of top two life insurers in Indian insurance industry.

- To evaluate the key determinants affecting the financial performance of selected two life insurers during time period taken under the study.

- To determine the impact of liquidity, solvency, leverage, size, age and equity capital on the profitability of life insurers.

\section{RESEARCH METHODOLOGY}

Data was collected from secondary sources. The secondary data were collected from relevant annual reports of Insurance Regulatory and Development Authority (IRDA), annual reports of PLIC, monthly IRDA Journals, various issues of Life Insurance Today, Insurance Times. The data were also collected by visiting Libraries of various Universities. Besides, a few websites have been consulted.

For determining the financial performance, financial ratios like solvency ratio, leverage ratio, quick ratio, return on equity ratio were calculated for each life insurer. Results have been computed by using SPSS.

\section{Research Tools}

The study applied multiple linear regression models to measure the extent to which, these determinants exert impact on life insurer's profitability. For this purpose, the firm's characteristics such as solvency ratio, leverage ratio, quick ratio, equity capital, size of the company, age of company were regressed against return on equity. The assumptions of regression analysis like multi colinearity, auto correlation have been checked. For determining the financial performance, financial ratios like quick ratio, solvency ratio, return of equity ratio and leverage ratio were calculated for each life insurers, taking into consideration liquidity, solvency, profitability and leverage of the company. 


\section{Determining Impact of Variables on Profitability}

The multiple regression models are used to examine the relationship between the profitability of Indian life insurance companies and explanatory variables. Regression is basically a statistical technique that predicts the value of dependent variable based on one or more independent variables. To measure the profitability of life insurance companies, Multiple linear Regression Model has been developed for the study.

Model: $\mathrm{ROE}=\alpha+\beta_{1} \mathrm{LNAGE}+\beta_{2} \mathrm{LNSIZE}+\beta_{3} \mathrm{LNLEV}+\beta_{4} \mathrm{LNQR}+\beta_{5} \mathrm{LNEQ}+\mathrm{Ei}$

\section{Hypothesis Framed}

To achieve the objectives, the study tested the following null hypotheses:

Dependent Variable Return on Equity (ROE)

H01: There is no significant relationship between age of company and return on equity.

H02: There is no significant relationship between size and return on equity.

H03: There is no significant relationship between solvency and return on equity.

H04: There is no significant relationship between insurance leverage and return on equity.

H05: There is no significant relationship between liquidity and return on equity.

Table 1 shows Regression Analysis between dependent variable (ROE) of ICICI Prudential and independent variable (age, size of company, solvency ratio, leverage ratio, quick ratio \& equity capital).

\section{ICICI Prudential Life}

Table 1: Regression Analysis

\begin{tabular}{|l|c|c|c|c|c|}
\hline \multicolumn{1}{|c|}{ Independent Variable } & Coefficient & Std. Error & t-Statistic & Prob. & VI F \\
\hline C & -1.190437 & 0.700308 & -1.699877 & 0.2313 & 0.490431 \\
\hline AGE & -0.089435 & 0.062376 & -1.433814 & 0.2880 & 0.003891 \\
\hline SIZE & $-2.07 \mathrm{E}-06$ & $2.56 \mathrm{E}-06$ & -0.808426 & 0.5037 & $6.56 \mathrm{E}-12$ \\
\hline SOLVENCY & 0.196585 & 0.165098 & 1.190720 & 0.3559 & 0.027257 \\
\hline LEVERAGE & 0.145037 & 0.034232 & 4.236930 & 0.0514 & 0.001172 \\
\hline QUICK & 2.859448 & 1.077944 & 2.652687 & 0.1176 & 1.161964 \\
\hline EQUITY & 0.000119 & 0.000758 & 0.156561 & 0.8900 & $5.74 \mathrm{E}-07$ \\
\hline R-squared & & 0.986838 & \\
Adjusted R-squared & & 0.947353 & \\
F-statistic & & 24.99275 & \\
Prob(F-statistic) & & 0.038968 & \\
\hline
\end{tabular}

Table 1 shows the model summary of the regression for the ICICI Prudential insurance company. It identifies the relationship between dependent variable (ROE) of ICICI Prudential and independent variable (age, size of company, solvency ratio, leverage ratio, quick ratio \& equity capital). Regression analysis shows that age of the company \& size have negative relationship with ROE, whereas, solvency ratio, quick ratio \& equity capital have positive but insignificant relationship. Among all variables, only leverage ratio \& quick ratio are important determinants of ROE, after allowing for influence of other variables in the model, as it has significant relationship with ROE a per cent and 10 per cent level of significance, so on the basis of the analysis, H04 and H05 has been rejected at 5 per cent and 10 per cent level of significance, whereas, H01, H02, H03, H06 has been accepted. 
From the table, it is found that variance inflation factor(VIF) value for all the variables is under acceptable limits, which indicates that the model is free from multi-co linearity problem. Hence, regression model is fit to be applied.

The value of $\mathrm{R}$ square is 98 per cent, which means that 98 per cent changes in the dependent variable i.e. ROE is due to the variables in the independent variables used in the model. The value of probability F-test in the model is equal to 0.03 , which suggests a linear relationship among the variables. As it is low, it can be concluded that independent variables are important determinants of dependent variable (ROE).

Table 2 shows Regression Analysis between dependent variable (ROE) of HDFC Life and independent variable (age, size of company, solvency ratio, leverage ratio, quick ratio \& equity capital).

\section{HDFC Standard Life}

Table 2: Regression Analysis

\begin{tabular}{|l|c|c|c|c|c|}
\hline \multicolumn{1}{|c|}{ Variable } & Coefficient & Std. Error & t-Statistic & Prob. & VI F \\
\hline C & -0.786118 & 0.469930 & -1.672839 & 0.2363 & 0.220834 \\
\hline AGE & 0.148248 & 0.037003 & 4.006393 & 0.0570 & 0.001369 \\
\hline SIZE & $-4.80 \mathrm{E}-07$ & $1.33 \mathrm{E}-06$ & -0.361603 & 0.7523 & $1.76 \mathrm{E}-12$ \\
\hline SOLVENCY & -0.008252 & 0.058600 & -0.140810 & 0.9009 & 0.003434 \\
\hline LEVERAGE & 0.003272 & 0.018245 & 0.179353 & 0.8742 & 0.000333 \\
\hline QUICK & 0.069580 & 0.244684 & 0.284368 & 0.8029 & 0.059870 \\
\hline EQUITY & -0.000341 & 0.000137 & -2.488088 & 0.1306 & $1.88 \mathrm{E}-08$ \\
\hline R-squared & & 0.992262 & \\
Adjusted R-squared & & 0.969048 & \\
F-statistic & & 42.74432 & \\
Prob (F-statistic) & & & 0.023035 & \\
\hline
\end{tabular}

Table 2 shows relationship between dependent variable (ROE) of HDFC Std. life \& independent variables.

Regression analysis shows that size of the company, solvency ratio \& equity capital of the company have negative relationship with ROE, whereas, leverage ratio \& quick ratio has positive, but insignificant relationship with ROE. Among this, independent variable, age of the company is the important determinants of ROE in the model, as it has significant relationship with ROE at 5 per cent level of significance. So on this basis, we reject H01 at 5 per cent level of significance whereas, H02, H03, H04, H05 has been accepted.

From the table, it is found that VIF value for all the variables is under acceptable limits, which indicates this model is free from multi-collinearly\& hence regression model is fit to be applied.

The value of $\mathrm{R}$ square is 99 per cent, which means that 99 per cent changes in the dependent variables i.e. ROE is due to changes in these six explanatory variables. The $\mathrm{P}$ value of the estimated $\mathrm{F}$ test in the model is very low i.e.0.02, which shows that the chosen six independent variables are important determinants of the depended variable (ROE). As smaller the value of $\mathrm{F}$ test, the greater is the evidence against the null hypothesis.

\section{CONCLUSIONS OF THE STUDY}

The study has aimed to evaluate the financial performance of top two life insurance companies through analyzing the determinants of their profitability. Measuring the performance of insurance companies has gained lot of importance, because they are not only providing the mechanism of saving money and transferring risk, but also helps to channel funds in an appropriate way from surplus economic units to deficit economic units, so as to support the investment activities in 
the economy. For measuring financial performance, financial ratios such as quick ratio, solvency ratio, return on equity and insurance leverage ratio have been calculated. The study evaluated that among these two private life insurers, HDFC Life have sound liquidity position. In case of solvency position, life insurer ICICI Life have higher solvency ratio as compared to other. Return on equity measure of both sounds good. The ratio is stable and presents a healthy picture of life insurers. As far as leverage analysis is concerned, the performance of HDFC Life is far better than ICICI Life.

Regression analysis shows that among the independent variables, age, size of the company, solvency ratio and quick ratio are significantly contributing to ROE. While the variable age is significantly \& positively contributing to ROE, the other variables size, solvency ratio and quick ratio significantly \& negatively contributes to it. It is therefore, imperative to identify factors which can help insurance companies and investors to increase their profitability.

\section{REFERENCES}

1. Kannan and Thangavel (2008) “Overview of Indian Insurance Sector”, Academic Open Internet Journal, Vol. 22, pp 1-14.

2. Kumar, Jogendra. (2008) “Life Insurance Industry - Past, Present \& The Future”, Bimaquest, Vol. VIII, Issue 1, January, pp. $41-49$.

3. Kumara swami, Rajiv (2011) “Risk Management for Insurers”, IRDA Journal, March, Vol. IX, No. 3, pp. 5-11.

4. Narindra and Taneja, (2004), "Insurance in India - Challenges and opportunities", The Insurance Times, November, Vol. 24, No. 11, pp. 34-37.

5. Parekh, Ashvin (2011) “IFRS in Insurance Industry”, IRDA Journal, May, Vol. IX, No. 5, pp. 5-8.

6. Sabera (2007), "Privatization of Insurance Industry in India - The Growth”, Insurance Chronicle, January, pp. 36-39.

7. Suresh (2009) “Recipe for successful Life Insurance Business”, IRDA Journal, March, Col. VII, No. 8, pp. 27-30

8. Vijayalakshmi, B (2007), "Impact of Globalization: An overview of Insurance Industry in India”, Life Insurance Today, September, Vol. 3, No. 6, pp. 5-8. 
